\title{
THE TEACHER AS A REFLECTIVE PRACTITIONER: A QUALITATIVE DESCRIPTIVE CASE STUDY OF TEACHING GRADE 4 IN A PROVINCE OF INDONESIA
}

\author{
Wiputra Cendana \\ Universitas Pelita Harapan \\ Email: wiputra.cendana@uph.edu
}

\begin{abstract}
Abstrak
Tujuan dari penelitian tindakan kelas ini adalah untuk melihat signifikansi dari refleksi. Refleksi ini berguna untuk meningkatkan pelatihan mengajar dalm memiliki karakter yang mempengaruhi pembelajaran siswa. Penelitian tindakan kelas ini mengambil tempat di salah satu sekolah di Makassar, provinsi Sulawesi Selatan. Penelitian tindakan ini diselesaikan di sebuah ruang kelas yang terdiri dari 22 siswa pada kelas 4 . Penulis menggunakan 3 siklus untuk menggambarkan pertumbuhan yang meningkat baik bagi penulis dan siswa. Untuk mengumpulkan data, penulis menggunakan beberapa instrument seperti dokumentasi (rencana pembelajaran, umpan balik pelajaran, foto dan rekaman video), refleksi penulis, hasil nilai siswa, surat siswa dan sebuah portfolio praktikum. Melalui penggunaan refleksi diri oleh penulis selama praktikum, penulis menyadari bahwa refleksi diri membantu penulis dalam meningkatkan cara penulis berpikir dan bertindak dalam pelatihan mengajar.
\end{abstract}

Kata kunci: Refleksi, Guru, Penelitian Tindakan Kelas

\begin{abstract}
The purpose of this classroom action research was to see the significance of selfreflection. This reflection is useful to improve teaching practice of having a character to affect students' learning. This classroom action research took place in one of the private schools in Makassar, South Sulawesi province. The action research was done within a classroom that consists of 22 grade 4 students. The writer used three cycles to describe the progressive growth of both the writer and the students. For gathering data, the writer used several instruments such as documentation (lesson plans, feedback on lessons, and video recording), the writer's reflection, students' grade reports, students' letters and a practicum portfolio. Through the use of the writer's self-reflection during this practicum, the writer realized that self-reflection helps the writer to improve his way of thinking and acting in his teaching practice.
\end{abstract}

Keywords: Reflection, Teacher, classroom action research

\section{Introduction}

Today, in shaping the minds of students, the existence of good schools is strongly needed around the world. In order to have a good school, the school needs to constantly improve itself. The performance of teachers is one part of the quality improvement plan of the school. 'Teachers' quality matters; knowledge and skills are the most vital in-school factors influencing children's learning (Leigh \& Mead, 2005)." The school that had been observed for this study was one of the many primary private schools in Makassar. The schools' curriculum that is being used was a National Plus. The economic level of the students at this school ranges from the middle to high economic level classes.

The maximum number of students in each class was 22. Teachers are 
expected to build academic proficiency and character by encouraging the students with the statements below:

- 'Saying 'I can' will increase your achievement"

- "Every student is a VIP (Very Important Pupil)"

- "We will have a great time together during academic year"

- "I appreciate your effort" and

- "Learning will happen if you make a mistake"

This school received the student teacher and writer for a teaching practicum as a requirement from Universitas $X Y Z$ in Tangerang. For any student teacher who taught in that school, it is the student teacher guidelines to have a mentor for the improvement of the student teacher's practice.

The student teacher was required to make lesson plans prior to teaching each lesson, and then in the process of applying the lesson plan, a mentor observed the student teacher actually applying the lesson plan to the classroom. After constructive criticism by the mentor, the student teacher is asked to reflect on their teaching practice as a way for them to improve the application of the lesson plan.
The importance of the reflection that was written by the student teacher is that it helps the student teacher to improve themselves and their teaching practice. As was said by McNergney \& McNergney, a reflection is the process of thinking about what student teachers have done and how they need to improve (2007, p. 177). A student teacher needs to do reflection everyday to shape their own philosophy about the education.

This paper will study the significance of using the writer's personal selfreflection to improve his teaching practice. It will also examine how the self-reflection of the writer can affect the student academic performance and character in the school and how the selfreflection helps the writer to be better teacher.

The study will discuss the relationship between the significance of self-reflection related to teaching practice. It can be a good way to achieve successful experiences for the beginning teacher. It also provides the implications of selfreflection towards students' academic performance and character. Selfreflection also contributes to a deeper understanding of the process of transformative education. Self-reflection is useful and helpful to the process of 
making a difference as a teacher as the transformative agent in the school.

\section{Methods}

The problem that the writer has described brought the writer to find the answer through his description of research. According to Tuckman (1999, p. 4), research is a systematic attempt to provide an answer to questions. Research in education is different from other types of research for other fields of study. Anderson explains that "research in education is a disciplined attempt to address or solve problems through the collection and analysis of primary data for the purpose of description, explanation, generalization, and prediction" (as cited in Burton \& Bartlett, 2005 , p. 15). In this study, the writer uses action research as the method for improving his teaching practice using personal reflection. "Action research is curriculum development. It is concerned with how to improve educational practice and its practitioners who carry out the research in examining and developing their teaching" (ibid, p. 37). The writer used action research because it has several benefits. One of the benefits is as Reason defined that action research's benefit can help (the writer) in "transforming organizations and communities to act self-reflectively and collaboratively within everyday practice" (as cited in McMillan \& Wergin, 2006, pp. 174-175). The writer used action research to transform in his teaching practice using self-reflection on previous teaching practices.

Action research can be divided into qualitative and quantitative research. The descriptive qualitative research collected the data presented through description, rather than statistics (Bogdan and Biklen as cited in Sugiyono, 2007 , p. 21). The writer decided to use the qualitative research because the problem in this study is a matter of selfreflection. Self-reflection cannot be measured by number and statistics.

The classroom action research design that was used in this study is the cycle described by Kemmis and McTaggart adapted by Hopkins who moves through the major steps of planning, action, observation and reflection (as cited in Young, Rapp, and Murphy, 2008, p. 2). This research was described in three cycles, with planning, acting, observing, and reflection each cycle (Figure 1). The writer worked with homeroom teacher $(\mathrm{HT})$ or teacher mentor (TM) during each cycle of these cycles

(Figure 2). 


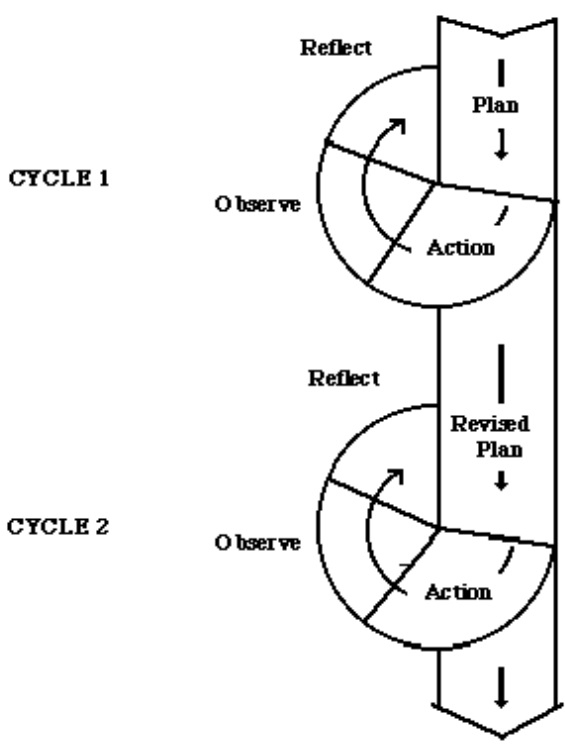

Figure 1 Action Research Process

(Adapted from Hopkins, 1985, as cited in Young, Rapp, and Murphy)

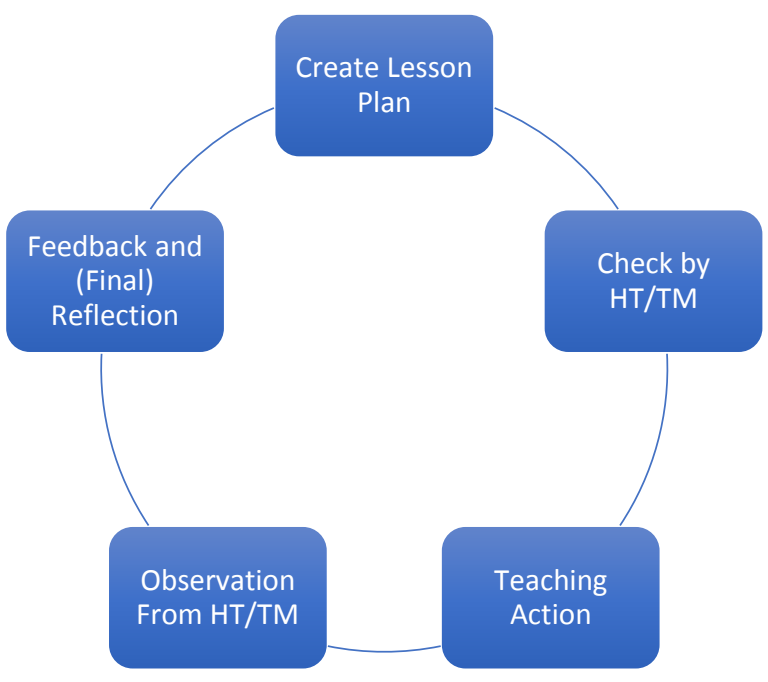

Figure 2: Classroom Action Cycle

Results and Discussion

In analyzing the data, the writer found the most used tool was the writer's personal self-reflection, on how to improve his teaching practices with a goal of instilling values. The second focus to be emphasized is the effect of the writer's self-reflection on the students' academic progress and attitudes in school.

Feedback on the lesson

The lesson feedback from the homeroom teacher, Ms. X, the teacher mentor, Ms. Y, and the teacher educator, was very useful in giving the writer advice while he reflected on his previous 
teaching. This was evident in what the teacher educator wrote, "I saw from his reflection (the writer) has changed to be more patient..., more organized..., more humble". Each feedback encouraged the writer to continue his improvement in his teaching. Ms. $X$ and Ms. $Y$ have taught over 5 years each and their teaching experience and suggestions helped the writer to grow professionally as a reflective practitioner teacher. The writer believes that his role as a Christian teacher was strongly influenced by writing reflections. The writer agreed with the equation that Posner suggested about the way of learning to teach through experience and reflection.

\section{Experience + Reflection $=$ Growth}

Through experience and reflection, the writer has developed significantly as a reflective practitioner teacher.

Student's achievement and attitude

In teaching, the teacher should have an approach to his teaching. This includes God-centered teaching practices. This means that during class, all the learning should point to God. And keeping God's Word in mind, teachers should then develop a learning process uniquely tailored for each student. This learning process is oriented to each student's interests and requires the teacher to work with the students closely enough to develop a personal relationship with the students. This relationship that a teacher has with students will impact the students' life and hopefully allow them to invite each student to a personal relationship with God. Teachers can impact not only students' lives, but also their achievement, character and eternal life. This type of transforming teaching is a characteristic of teachers. This requires teachers that are always directed by God's wisdom.

The writer realized when he started to improve his teaching; it was also helping the students to improve their learning. Through the use of selfreflection, the writer was able to improve his firmness and consistency in rehearsing and reminding the class of proper procedures. Students became more organized, tidy, ready, and responsible and honored the teacher and class procedure. The reason that the students became more organized and compliant to the rules was that the teacher also modeled these attitudes during the process of learning.

The school is a place for teacher and student to learn on a day to day basis. It was not only the teacher who needed to progress through the 
ISSN 2548-9119

reflection, but also the students showed that they are progressing.

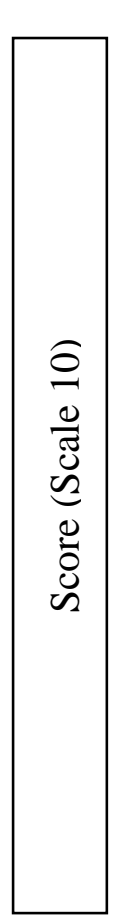

Graph 1: Science Test Score (Concept / Skill)

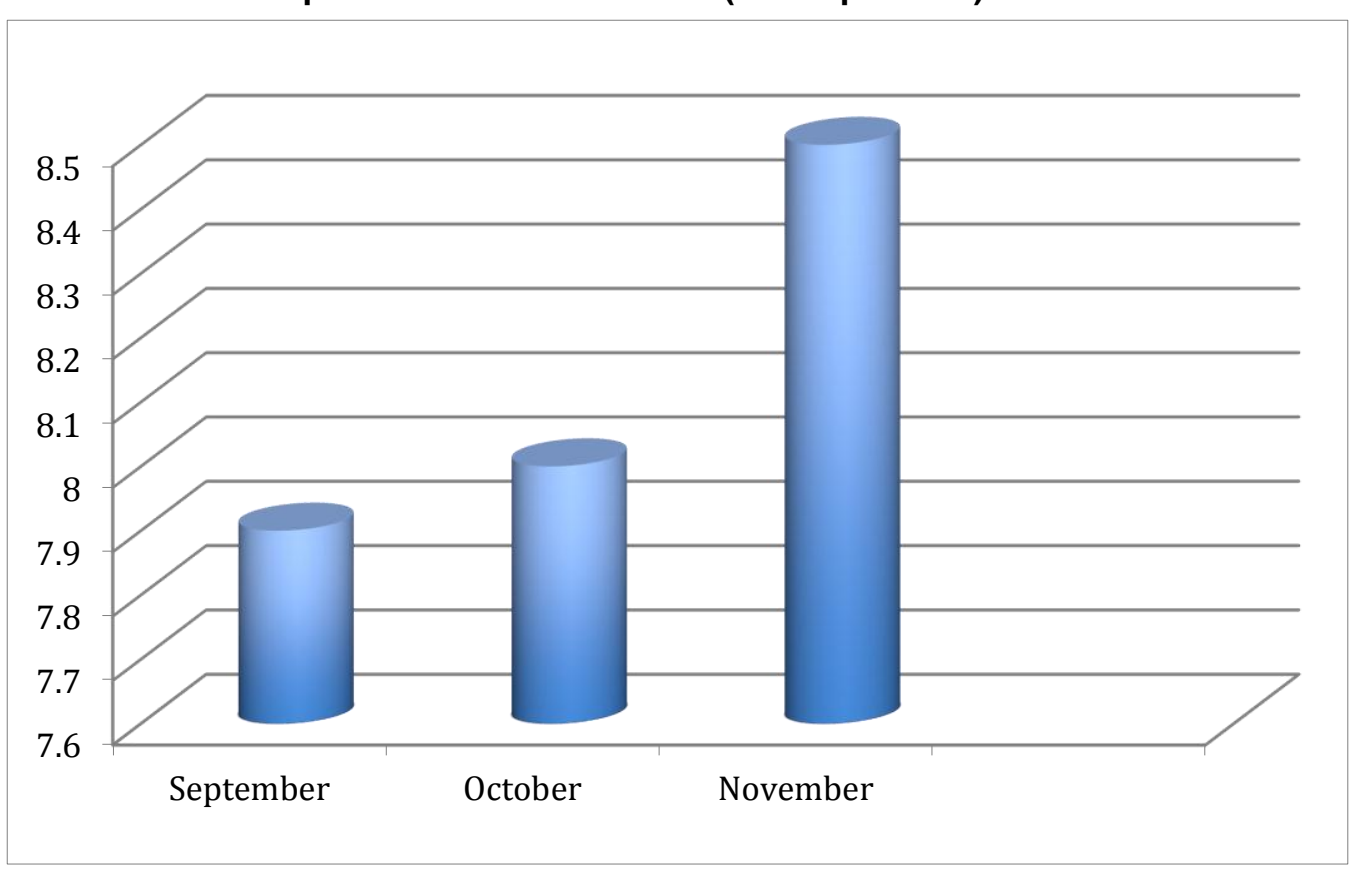

Graph 2: Listening / Speaking Skill Score

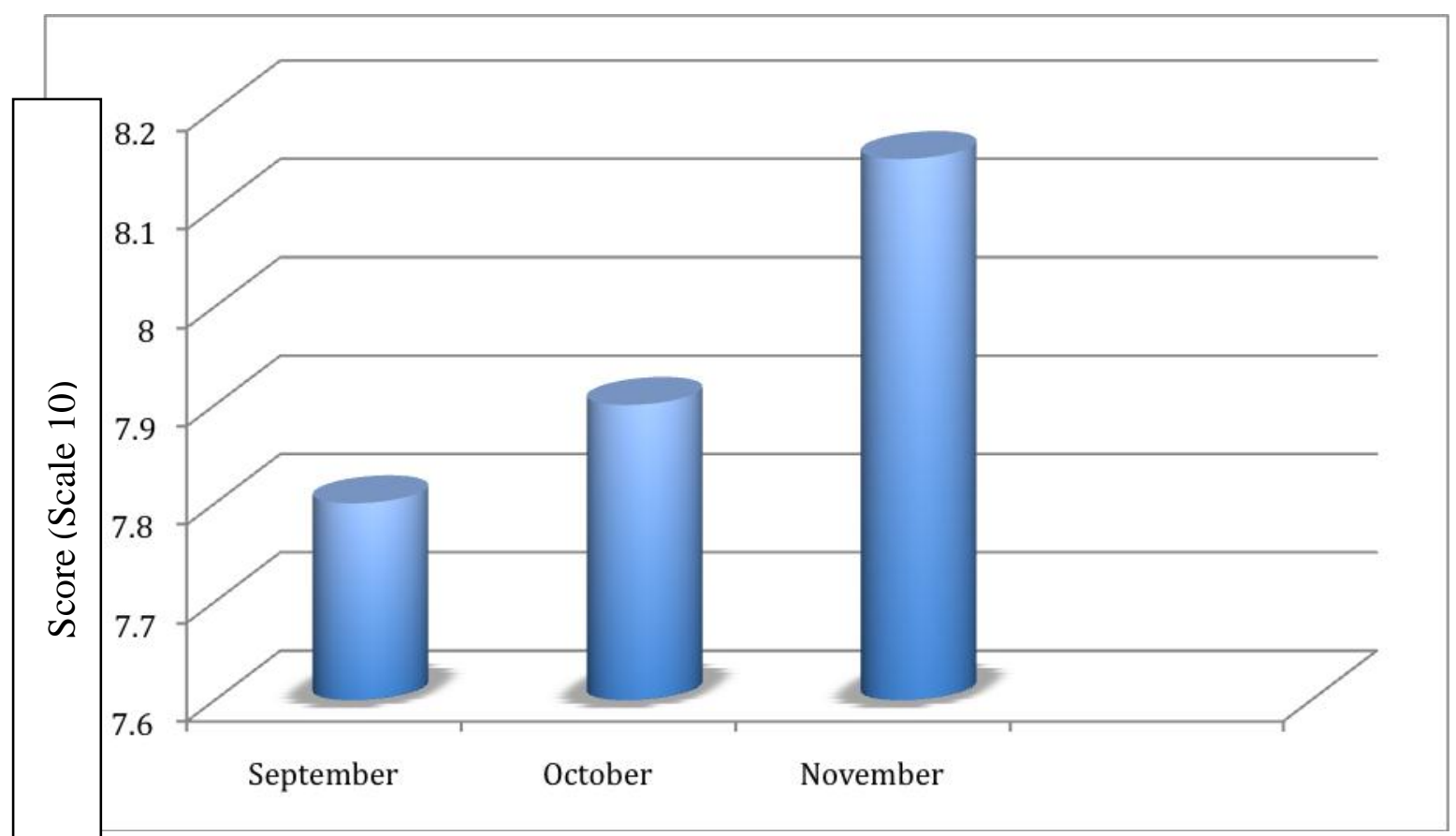

The writer concludes that through improved. The importance of this study self-reflection, both the writer's and was the process by which the writer students' academic growth has been changed himself using reflection and 71 | The Teacher As A Reflective Practitioner: 
how this affected his teaching action and in turn affected the student's learning. The use of self-reflection is evident in the way the writer thought and acted.

\section{Conclusions}

The personal self - reflection in a teaching practice is an effective way for the writer as the beginner teacher to improve on their teaching practice. The self-reflection influenced how the writer changed the method of teaching and this led to the improvement of the students' academic performance and character development in the learning process.
The process of change was not instant but it consumed much time to reflect more in order to improve the writer's way of thinking and acting. The final goal in using this self-reflection was to be enhance the writer viewed the students and treated them according to the respectful way. The writer could not conduct the reflection by himself; he also needed feedback from his homeroom teacher and teacher mentor. It was a good model on how teachers support each other as a positive and constructive community in the school.

\section{References}

Burton, D., \& Bartlett, S. 2005. Practitioner research for teachers. London: Paul Chapman

Cresswell, J. W. 2005. Educational research: Planning, conducting, and evaluating quantitative and qualitative research $\left(2^{\text {nd }}\right.$ ed.). New Jersey: Pearson Educational Inc.

Darling-Hammond, L. 2006. Powerful teacher education: Lessons from exemplary programs. San Fransisco: Jossey-Bass.

Fraenkel, J. R., \& Wallen, N. E. 2008. How to design and evaluate research in education $\left(7^{\text {th }}\right.$ ed.). New York: McGraw Hill Companies.

Johns, C. 2009. Becoming a reflective practitioner ( $3^{\text {rd }}$ ed.). Singapore: WilleyBlackwell. Retrieved January 23, 2010, from http://books.google.com/books?id=uvNiZvYpsu4C\&printsec=frontcover\&dq=reflec tive \& $\mid r=$ lang en\&as drrb is $=b$ \&as minm is $=0$ \&as miny is $=2000$ \&as maxm is $=$

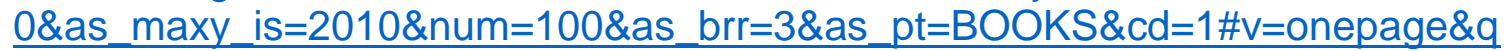
$=\& \mathrm{f}=\mathrm{false}$

Johnson, D. W., \& Johnson. R. T. 1999. Learning together and alone ( $5^{\text {th }}$ ed.). United States of America: Allyn and Bacon.

Jones, J., Jenkin, M., \& Lord, S. 2006. Developing effective teacher performance. London: Paul Chapman Publishing. 
Leigh, A., \& Mead, S. 2005, Lifting teacher performance. Retrieved January 19, 2010, from http://www.ppionline.org/documents/teachqual 0419.pdf

Marsh, C. (2004). Becoming a teacher: Knowledge, skills and issues ( ${ }^{\text {rd }}$ ed.). Australia: Pearson Education Australia.

McMillan, J. H., \& Wergin, J. F. 2006. Understanding and evaluating educational research $\left(3^{\text {rd }}\right.$ ed.). New Jersey: Pearson Education.

McNergney, R. F., \& McNergney, J. M. 2007. Education: The practice and profession of teaching. United States of America: Pearson Education.

Sugiyono. 2007. Metode penelitian pendidikan: Pendekatan kuantitatif, kualitatif dan $R \& D$. Bandung: Alfabeta.

Tuckman, B. W. 1999. Conducting educational research ( $5^{\text {th }}$ ed.). United States of America: Harcourt Brace College).

Van Brummelen, H. 2009. Walking with God in the classroom: Christian approaches to teaching and learning $\left(3^{\text {rd }}\right.$ ed. $)$. United States of America: Purposeful Design Publications.

Wandberg, R., \& Rohwer, J. 2003. Teaching to the standards of effective practice: $A$ guide to becoming a successful teacher. United States of America: Pearson Education.

Wong, H. K., \& Wong, R. T. 1998. How to be an effective teacher: The first days of school. Singapore: Harry K. Wong Publication.

Young, M. R., Rapp, E., \& Murphy, J. W. 2008. Action research: Enhancing classroom practice and fulfilling. Journal of Instructional Pedagogies. Retrieved February 10, 2010, from http://www.aabri.com/manuscripts/09377.pdf 